\title{
ACRL "Excellence in Academic Libraries" winners hold celebrations
}

The North Carolina State University (NCSU)Libraries staged a festive celebration on March 21, 2000, in honor of its selection as the first recipient of ACRL's Excellence in Academic Libraries Award in the university category. Nearly 200 individuals enjoyed an elegant luncheon before the official ceremony began. Among those attending were library staff members, current and retired library administrators, university administrators and faculty, members of the Friends of the Library Board of Directors, state legislators, and special guests. Each guest received a goldplated commemorative bookmark from the libraries and a red button supplied by ACRL that read, "NCSU Libraries: Best of the Best."

Larry L. Hardesty, president of ACRL, for-

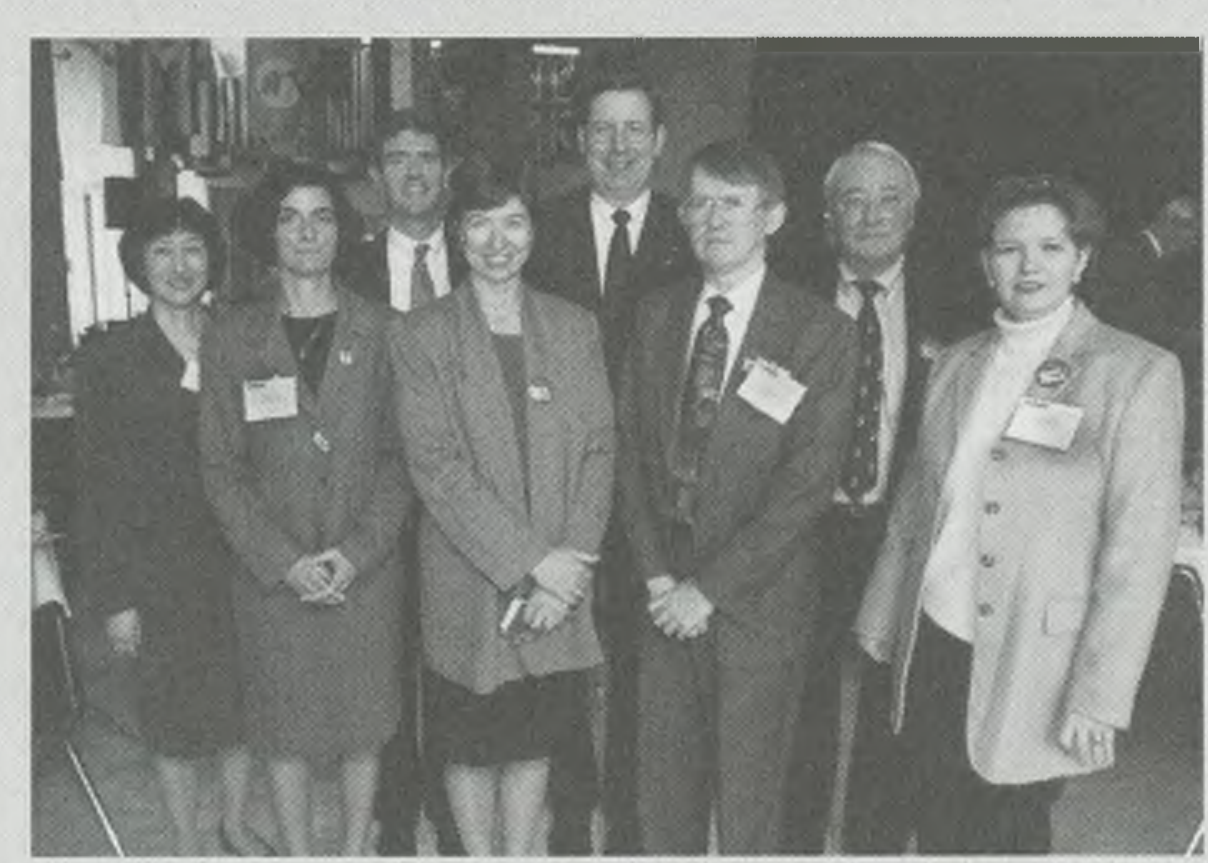

ACRL President Larry Hardesty and Blackwell's Book Services Don Satisky presented the award to NCSU officials. North Carolina legislators and author Kaye Gibbons also attended the event. mally presented the handsome crystal award to NC State Chancellor Marye Anne Fox and Provost Kermit L. Hall. Hall expressed his admiration for Susan Nutter's outstanding leadership as library director before announcing the library's latest ARL ranking, a rise to 35 out of 111 academic research libraries.

Following the award presentation, Donald Satisky, vice president for international sales and marketing for Blackwell's Book Services, Inc., delivered a $\$ 3,000$ check to Jinnie $Y$. Davis, assistant director for Scholarly Communication and External Relations. Davis was representing Vice Provost and Director of Libraries Susan K. Nutter, who was unable to attend the ceremony because of surgery.

Friends of the Library's Author-in-Residence, internationally acclaimed writer Kaye Gibbons, lovingly described her many years of association with the NCSU Libraries. She worked there during her undergraduate days at the university, and she recalled vividly her first encounter with newly hired library director Susan Nutter from MIT. She claimed she just sauntered right into Nutter's office one day and said, "I understand you're from 'up there' and you're going to have this place full of computers and I want it smelling like books." Gibbons added she wanted the library to always smell like books, which Nutter promised to do. From this initial encounter, the Author-in-Residence program blossomed, with Kaye Gibbons providing unstinting support, talks, and donations to an institution she cherishes.

Altogether, it was an occasion that encompassed the entire university and accomplished the Excellence in Academic Libraries Award program's goal of achieving campus recognition of awardwinning libraries. Publicity about the award resulted in an editorial in the Raleigh newspaper praising the NCSU Libraries' achievements while noting the need to sustain its momentum.-Terrell A. Crow, e-mail: terry_ crow@ncsu.edu, and Jinnie Y. Daivs, NCSU Libraries, e-mail: jinnie_davis@ncsu.edu

\section{College of DuPage and Wellesley College Libraries}

$E d$. note: The College of DuPage Library, winner in the community college category, will hold a reception on May 10 at 5:30 p.m., hosted by the Board of Trustees. Althea Jenkins, executive director of ACRL, will present the plaque, and a representative of Blackwell's Book Services will present the check.

Wellesley College Library, winner in the college category, plans a ceremony on the steps of the Margaret Clapp Library with an outdoor reception to follow on Monday, May 15 from 4:00-6:00 p.m. Speakers at the ceremony will include Wellesley College President Diana Chapman Walsh, and Dean of the College Lee Cuba. 